
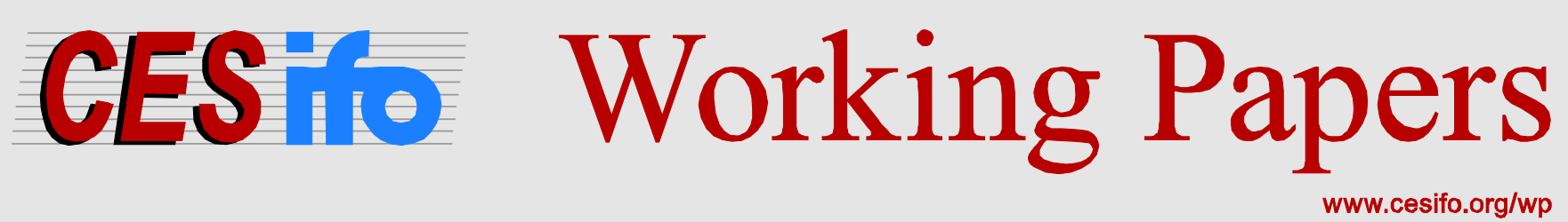

\title{
Spatial Concentration of Military Dictatorships in Sub-Saharan Africa (1977-2007)
}

\author{
Raul Caruso \\ Ilaria Petrarca \\ Roberto Ricciuti
}

CESIFO WORKING PAPER NO. 4802

CATEgory 2: Public ChOICE

MAY 2014

An electronic version of the paper may be downloaded

- from the SSRN website:

- from the RePEc website:

- from the CESifo website:

WWW.SSRN.com

www.RePEc.org

www.CESifo-group.org/wp

\section{CESifo}




\title{
Spatial Concentration of Military Dictatorships in Sub-Saharan Africa (1977-2007)
}

\begin{abstract}
We empirically investigate the existence of spatial autocorrelation between military dictatorships in Sub-Saharan Africa from 1977 through 2007. We apply a Bayesian SAR probit regression, extended to a pooled model. We find a robust and positive spatial autocorrelation coefficient, which shows a spatial concentration of military autocracies. In particular, in the aftermath of Cold War military regimes cluster in the central region. Among covariates, interestingly, foreign aid shows a positive association with military regimes during the Cold War while it turns to exhibit a negative association after 1989. With regard to other economic covariates, we find that: a) there is a negative association between GDP per capita and the existence of a military autocracy; b) a larger manufacturing sector is associated with a smaller probability of a military rule; c) a larger mining sector is associated with a higher likelihood of military rules; d) trade openness reduces the likelihood of militarization.
\end{abstract}

JEL-Code: C210, H110, N470.

Keywords: military dictatorship, Sub-Saharan Africa, Bayesian SAR probit model, spatial autocorrelation, diffusion, concentration.

Raul Caruso

Catholic University of the Sacred Heart

Centre for Applied Economics (CSEA)

Milan / Italy

raul.caruso@unicatt.it
Ilaria Petrarca

University of Verona

Verona / Italy

ilaria.petrarca@univr.it

\author{
Roberto Ricciuti \\ University of Verona \\ Verona / Italy \\ roberto.ricciuti@univr.it
}

A preliminary version of this paper has been presented at the European Public Choic Society 2014 in Cambridge. We warmly thank the discussant Martin Gassebner and the participants Gilberto Turati, Umberto Galmarini, Klaas Staal, Kristina Kis-Katos. Special thanks also to Mario Maggioni for some general discussions on the topic of this paper. 


\section{Introduction}

In this paper we study whether or not there was a spatial autocorrelation between military regimes in Sub-Saharan Africa from 1977 through 2007. In fact, global historical patterns present a clear-cut walk away from military rules. In 1972 military dictatorships accounted for $24.6 \%$ of the world countries, with $45.7 \%$ concentrated in Africa. Eventually, military regimes in 2010 ruled 7.5\% of the world countries, with a concentration of almost $50 \%$ of them in Africa. ${ }^{1}$ That is, in the period 1972-2010, the share of democracies increased from $28.2 \%$ to $54.0 \%$. According to famous definition provided in Huntington (1991) the world is experiencing the "third wave of democratization". Put briefly, we observed a sharp decrease in the number of military dictatorships that is possibly the effect of a 'global movement' towards democracy, with some local frictions that kept military dictatorships concentrated in Africa.

In what follows we investigate whether the probability that a country in SubSaharan Africa became a military regime increased as the share of neighbors governed by a military rule gets larger. Put differently, we search for spatial correlation between military regimes. In this respect, the claim that "any analysis of democratization that does not account for spatial relationships is underspecified" (Brinks and Coppedge, 2006: 482) is here generalized to "any analysis of the diffusion of government institutions". Following Strang (1991) we interpret the institutional diffusion as the process by which the "prior adoption of a trait or practice in a population alters the probability of adoption for remaining nonadopters". Then, a large body of recent literature shows that institutions are spatially interdependent. In what follows we aim to contribute to this literature by investigating whether the probability that a country in became a military regime increased as the share of neighbors governed by a military rule gets larger. Put differently, we search for spatial correlation between military regimes in SubSaharan Africa.

The interesting departure point of our analysis is that we investigate military regimes under the awareness that their number decreased in latest years. Secondly, we employ a broader definition of military regimes that embraces also those regimes characterized by the indirect influence of military on civil governments.

\footnotetext{
${ }^{1}$ Wahman et al. (2013).
} 
The analysis employs recent advancements in spatial econometrics. In particular, we apply a Bayesian SAR probit regression, extended to a pooled model. The results show that there is a robust spatial autocorrelation between military governments so confirming those produced in the literature with regard to democracies. More precisely, we can claim the existence of a concentration process of military regimes in Sub-Saharan Africa. Eventually, as robustness check we have re-estimated our spatial models for the sub-periods 1977-1989 and 1990-2007 in order to verify whether or not the global order of Cold War had a significant impact on regional diffusion of military regimes. We found that the spatial correlation is confirmed is positive and significant only after 1989. Put differently, once the global order of the Cold War vanished, regional factors and linkages became crucial to shape institutional landscape at regional level. The reversal of institutional landscape in the aftermath of Cold War is also confirmed by the results with regard to foreign aid. In the Cold War period it is positively and significantly associated with the existence of a military regime whereas in the post1989 period it turns to be negatively associated with military regimes. Evidently, since foreign aid mainly depends on political and strategic considerations, it is reasonable to say that in the Cold War period foreign aid was channeled towards allies irrespectively of their internal regime. Afterwards, in the aftermath of the Cold War, foreign aid did not contribute to militarization of the government but it rather prevented it.

In addition, economic covariates are in line with established results in the literature. Among others, consider: (i) there is a negative association between lagged GDP per capita and the existence of a military rule. In particular, in the light of the proper interpretation of GDP per capita as measure of long-run economic growth, we can maintain that poorer countries are more likely to turn into a military rule; (ii) a larger manufacturing sector is associated with a smaller probability of a military rule; (iii) the degree of openness is negatively related with the existence of a military rule. In this respect, it is reasonable to say that countries which are more integrated in the international economy are also more likely to be affected by the global movement towards democracy rather than a process of spatial concentration. 
The paper is structured as follows: in Section 2 we briefly review some related literature, Section 3 describes the data and the econometric methodology, and Section 4 reports the results. Section 5 concludes.

\section{The Background}

This paper is related to different strands of literature, at the cross-roads between economics and political science. First, this paper relates to a wide literature on spatial diffusion of institutional regimes. In recent years, diffusion models have been extensively studied to analyze the global widespread of democracy, economic liberalism and trade regionalism. Needless to say, fragmentation of Soviet Union and eastern enlargement of European Union favored a novel interest in diffusion processes. A global movement towards democracy has been verified by Starr (1991). The author presents an analysis of bordering governmental transition during the period 1977-1987, using variations in the Freedom House degree of political rights and civil liberties. He finds significant global and regional effects, but he warns that they are solely the trigger for a change, because the necessary prerequisite is that the country is ready for innovation in terms of their internal setting. Starr and Lindborg (2003), enriches the foregoing work by analyzing the period 1974-1996 so confirming that neighbor effects matter to explain institutional settings. Doorenspleet (2004) finds a geographical pattern of the transition to democracy: countries surrounded by more democratic neighbors tended to improve their level of democratization, and vice versa.

O'Loughlin et al. (1998) present a cautionary reasoning on the spatial diffusion of democracy universally. The authors show that the study of spatial diffusion of regimes would significantly benefit from considering 'domain-specific' factors. Brinks and Coppedge (2006) move a step forward and provide an explanation of the diffusion mechanism, modeling a process of "neighbor emulation" where bordering countries tend to converge towards a shared level of democracy or non-democracy. ${ }^{2}$ The core assumption is that countries are rewarded when their regimes are similar to those of their neighbors, and the differential in

\footnotetext{
${ }^{2}$ In an early contribution on the diffusion of dictatorships (Li and Thompson, 1975), emulation was one of the sources of spreading of coups, together with the roles of disinhibitor, negative example, and reference group.
} 
the index of democracy between bordering countries generates pressure for a change. The democracy index is defined by the authors according to the Freedom House sum of the degree of political rights and civil liberties, scaled in the interval from 2 to 14. The authors challenge the idea that diffusion is an econometric illusion generated by global trends, correlation among the disturbances or the regional clustering of domestic factors that is a severe issue especially in crosscountry datasets. The results of the empirical analysis confirm the presence of a pattern of diffusion of democratization across bordering states, the relevance of global trends and the stimulus represented by being in the US sphere of influence. Leeson and Dean (2009) also study whether the theory of democratic diffusion holds for a large panel of 180 countries in the period 1850-2000. Empirical findings show that some democratic contagion does exist but it is less relevant than those predicted by the model. Gassebner et al. (2013), in a gigantic study on determinants and survival of democracies for 165 countries in the period 19762002 , find that if a country has democratic neighbors survival of democracy is more likely.

More in general this paper also relates to works explaining the emergence of institutional spill-over. With specific regard to African countries, De Groot (2011) focuses on development of political freedoms and democracy. The author analyzes several path-dependent variables, such as the history of political freedom and also the improvements emerged in neighboring countries finding that an improvement of political freedom is associated with an increase in the probability of improvement in neighboring countries. Kelejian et al. (2013) show the existence of spatial spillover in institutional development. In particular, the authors adopt several measures of institutional quality using a spatial lagged dependent variable as main explanatory variable. The latter is a weighted average of institutional levels in continuous countries. Interestingly, as shown in Goel and Saunoris (2013), institutional spillovers take shape even for informal institutions. That is, the authors analyze the spatial spillover of corruption and shadow economy for a large panel of countries finding that both corruption and shadow economy exhibit spatial correlation.

Eventually, this work also draws insights from the recent literature that analyses the relationship between economic factors, autocracies and military governments. Classical references on economics of autocracy are Tullock 
(1987/2002), McGuire and Olson (1996) and Wintrobe (1998). Recent theoretical models describe an agency problem: within a polity the elite imposes predatory policies that generate pressures for civil war. The risk of social unrest increases as the income distribution becomes more uneven, a situation that is encouraged by weak state capacity, namely legal and fiscal capacity (Besley and Robinson, 2010; Besley and Persson, 2008, 2009). The scholars recognized two alternatives for the authoritarian regime to survive. First, autocrats may introduce legislative and partisan institutions to channel political opposition, co-opt external groups and decrease internal pressures (Gandhi, 2008). Second, the army is used to defend the governing elite from the risk of internal violence. As noted above, a larger army, however, reduces the opportunity-cost for the military to run a coup d'état and seize power, establishing a military rule (Acemoglu et al., 2010 and Besley and Robinson, 2010). The three main causes of coups that the authors predict are income inequality, ethnic fractionalization and external threat. Recently, Caruso et al. (2014) empirically supported the impact of economic variables and political factors on the probability of a military rule emerging from coups. In particular, it is shown that productive sectors as manufacturing are positively associated with the existence of a military rule even if a negative association does take shape with regard to per capita income.

\section{Hypotheses, data and methodology}

In what follows, we present our hypotheses, the data and the empirical strategy. The focus variable of this study is the military character of governments. We choose the relevant variable in the Authoritarian Regimes Dataset ${ }^{3}$ (Hadenius and Teorell, 2007; Wahman et al. 2013), where the military category ${ }^{4}$ is defined as 'the

\footnotetext{
3 The variable regime 1 ny is composed of the following categories: 1 Monarchy, 2 Military, 3 One party, 4 Multi-party, 9 No-party, 99 Other, 100 Democracy.

${ }^{4}$ Crucial to the development of this study is the choice of the dependent variable capturing the existence of a military autocracy. In fact, in choosing the military regime variable, we face the choice of a number of datasets. Compared with other dataset, the definition of the Authoritarian Regime Dataset is more encompassing. For example, in Geddes (1999), a regime is military when 'a group of officers decides who will rule and exercises some influence on policy'. Moreover, the Authoritarian Regimes Dataset explicitly aims at improving Geddes database, since it includes a number of nondemocratic regimes that were neglected, it uses a more stringent definition of 'personalist' regimes, and it make a distinction between one-party and dominant party regimes. ${ }^{4}$ The Database of Political Institutions (Beck et al., 2001) defines a military regime when the chief executive has a military rank, which on the one hand leaves out the external influence of the military (if the chief executive is a civilian) and, on the other hand, it does not consider the overall political system, which
} 
actual or threatened use of military force, referring to Military regimes, where the armed forces may exercise political power either directly or indirectly (i.e., by controlling civilian leaders behind the scenes). Regimes where persons of military background are chosen in open elections (which have not been controlled by the military) thus should not count as military.' The military category also includes rebel regimes, i.e., cases where a rebel movement has taken over the power by the use of force, namely by military means, and the regime has not been modified in another kind of regime. This category is particularly important in Africa, where these groups often seize power from existing regimes (Congo-Kinshasa from 1997 to 2003 is one example).

Figure 1 plots military and civilian regimes in $1975,1985,1995$, and $2005 .^{5}$ Dark-shaded countries denote military regimes. In 1975 we observe the existence of military regimes in the central area of Sub-Saharan Africa, in particular around the Democratic Republic of Congo. This area shrinks over time, with minor differences from 1975 to 1985, but faster afterwards, as the smaller areas of civil governments tend to progressively expand from the three original poles in which they were confined.

\section{Figure 1 - Military and civil regimes in Sub-Saharan Africa in selected} years
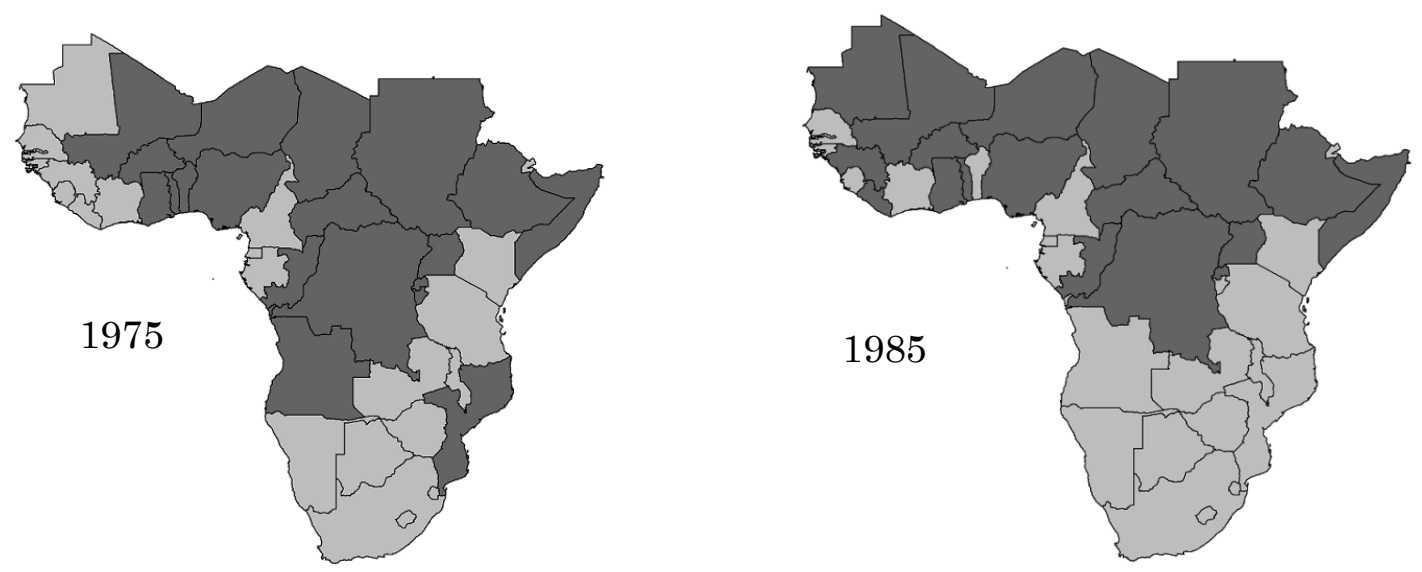

may not be a military dictatorship, even if the chief executive is a military supported by other powers. The same issue arises with the democracy-dictatorship indicator developed by Cheibub et al. (2010). Regan et al. (2009) consider a military regime as 'an executive [that] has the power to use military force abroad without legislative approval,' which appears to be too narrow for our purposes.

5 The list of the countries that we include in the analysis is provided in the Appendix. 

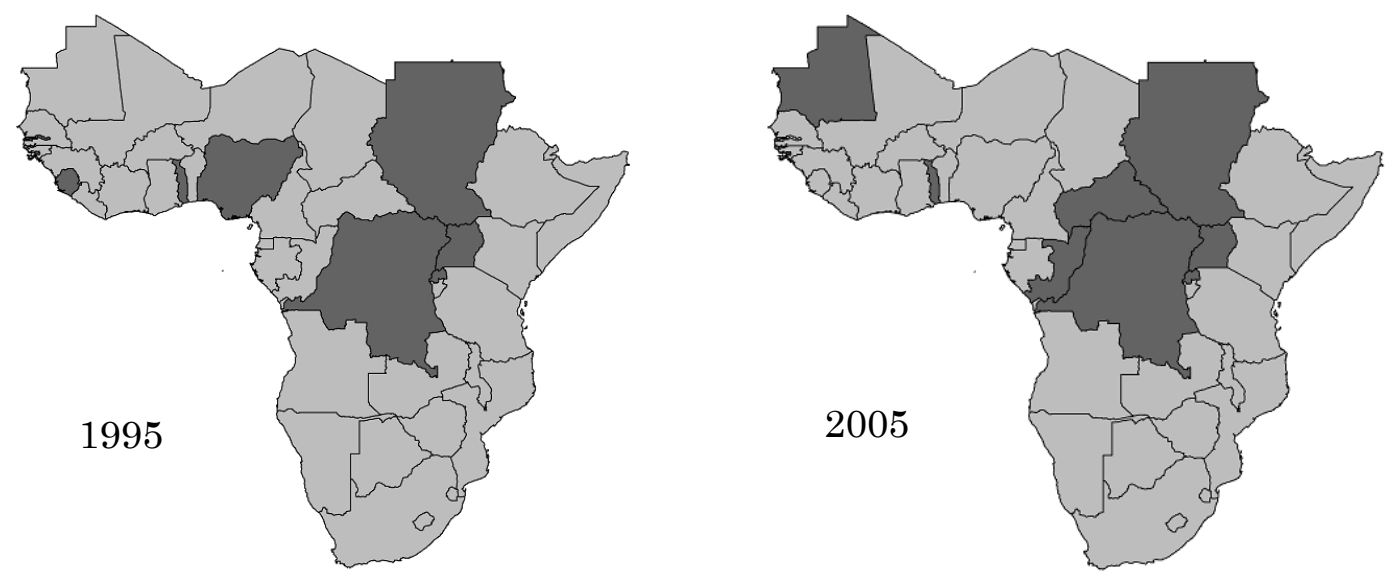

Hereafter, we analyze the diffusion of military dictatorships by estimating the interaction coefficients between the domestic regime and the neighboring ones. In other words, we empirically study whether the military nature of the government is reasonably influenced by the military nature of neighboring governments. More explicitly our hypotheses testing is:

$H_{1}$ : There is no spatial correlation between military governments in Sub-Saharan Africa. Consequently, military regimes would depend only on internal factors.

$H_{2}$ : There exists a positive spatial correlation between military rules in Sub-Saharan Africa.

If the null hypothesis is rejected, the military nature of one observation would be correlated with the one of nearby units. Therefore, we use spatial econometrics techniques. As noted above, the dependent variable, namely the military nature of the government, is binary, so implying severe computational issues. In fact, the likelihood function in the spatial context becomes an $\mathrm{N}$-dimensional integral, where $N$ is the number of observations (Franzese and Hays, 2009). Before specifying the empirical model, we briefly discuss this methodological point. The spatial econometric literature has developed several alternatives to the Maximum Likelihood to estimate the spatial probit model, i.e. the EM algorithm (McMillen, 1992), GMM (Pinkse and Slade, 1998), and the Bayesian MCMC (LeSage and Pace, 
2009). All these methodologies, however, present some shortcomings. In particular, the EM is computationally burdensome and provides inconsistent estimates, while the GMM ignores the spatial interaction effects among the error terms (for a discussion, see Elhorst et al., 2013). Regarding the Bayesian MCMC, although it makes it difficult to verify if the convergence actually occurred, it is faster and it is also the most popular in the empirical literature. The Bayesian routines are available in Matlab (LeSage, 2005) and $R$ (Wilhelm and Godinho de Matos, 2013). Furthermore, our choice of applying the Bayesian MCMC approach is in line with the recent common practice in the empirical literature [see among others Fiva and Rattso (2007), Horny et al. (2012), Seya et al. (2012), Schone et al. (2013), Brandt et al. (2011)].

In particular, following LeSage and Pace (2009), we specify the SAR probit model as:

$$
\text { Military }_{i t}=\rho \boldsymbol{W} \text { Military }_{i t}+\delta \boldsymbol{X}_{i t}+\varepsilon_{i t}
$$

where Military is a vector of observations of size $(N \mathrm{x} 1)$, where $i=1, \ldots, N$ is the number of observations. In particular, Military is a dummy equal to one if the ruler is a military junta and zero otherwise. In particular, we define the latent variable Military*. Military $=1$ if Military ${ }^{*} \geq 0 ;$ Military $=0$ otherwise. The spatial weight matrix $W(N \times N)$ describes the dependence structure between neighboring observations. We define two countries as neighbors if they share at least one common border. The scalar $\rho$ is the spatial autoregressive coefficient, and it is assumed to be bounded between -1 and $1 . \delta$ is a $(k \times 1)$ vector of parameters associated with the $(N \mathrm{x} k)$ data matrix $\boldsymbol{X}$, which we will specify later on. The error term is assumed to be normally distributed with mean 0 and unit variance.

The first step of the Bayesian approach is to set the prior distributions for Military* $\delta$ and $\rho$. Given the known Military data, the unconditional joint posterior distributions for Military*, $\delta$ and $\rho$ are estimated by sampling until convergence from the conditional distributions for all the model parameters. The sampling can be realized with a Markov Chain Monte Carlo and Gibbs sampling scheme, from this the name 'Bayesian MCMC' estimation. ${ }^{6}$

\footnotetext{
${ }^{6}$ For a detailed description of the model estimation, see LeSage and Pace (2009), chapter 10; for a technical implementation in $R$, see Wilhelm and Godinho de Matos (2013).
} 
If we would properly account for the longitudinal dimension of our dataset and exploit all the available information, we should apply a panel model. Unfortunately, an established econometric theory for the estimation of spatial panel probit models is not available yet, being the sketched model of Kakamu and Wago (2005) the unique contribution to the topic. Nonetheless, the Bayesian spatial probit model can be extended to a pooled model, by pre-multiplying the spatial weight matrix $W$ times an identity matrix $\boldsymbol{I}_{T}$ of size $T \times T$, where $T$ is the time period length. An application of a spatial Tobit SAR model is provided in Di Porto and Revelli (2011).

If we specify the time index $t=1, \ldots, T$ and unfold the $\boldsymbol{X}$ into its three main components, equation (1) becomes:

$$
\begin{aligned}
\text { Military }_{i t}= & \delta_{0} \\
& +\rho \boldsymbol{W M i l i t a r y}_{i t}+\delta_{1} \boldsymbol{E C O}_{i, t-1}+\delta_{2} \boldsymbol{G E O}_{i t}+\delta_{3} \boldsymbol{H I S T}_{i t}+\delta_{4} D E M_{t}+g_{t} \\
& +\varepsilon_{i t}
\end{aligned}
$$

The vector $\boldsymbol{E C O}_{i, t-1}$ includes some one-year lagged measures of economic performance. First, we include the real PPP GDP per capita (GDP pc) expecting a negative sign associated. In particular, following Caruso (2010) we expect that the sectoral shares of GDP also contribute to explain institutional (either formal or informal) aspects of economies. Therefore, we include the added value of the manufacturing (manuf) and mining sectors $(\min )$ as percentage of GDP. Caruso et al. (2014) found a positive association between the manufacturing share of GDP and the existence of a military rule. The degree of trade openness is included to account for the economic interdependence of the country. It is defined as the sum of imports plus exports over GDP. Oilprod is a dummy that captures whether a country is an oil-exporter or not. To take into account for the role of international organizations and multilateral agreements, we include the GDP share of Official Development Assistance $(O D A / G D P)$ and the number of IMF Arrangements agreed. For what concerns the computation of the $O D A / G D P$ ratio, we follow the approach of Collier and Dollar (2002) and use the real PPP GDP from the Penn World Tables. ${ }^{7}$

\footnotetext{
${ }^{7}$ We first compute the real PPP GDP by multiplying GDP $p c$ by the population size. The GDP is in constant 2005 dollars, while the $O D A$ flows are in current US $\$$ (source: World Bank, World Development Indicators). We converted the $O D A$ into constant 2005 US $\$$ by using the CPI index (downloaded from http://www.multpl.com/cpi/table) and applying the following formula:
} 
The vector $\boldsymbol{G E O}$ includes those variables capturing some geographic-fixed effects, as the Landlocked dummy and macro-areas dummies (Centre, East, West and South). Finally, the HIST vector includes two dummies that capture the past history: the British colonial heritage $(U K)$, and the Soviet Union influence during the Cold War (Soviet). The small sample size prevents us from including all the year dummies, therefore we account for time effects $g_{t}$ by means of a set of fiveyears dummies. Finally, we include the share of countries of the world that are coded as democratic in the Hadenius and Teorell (2007) dataset (world share of democracies). Needless to say, we excluded the Sub-Saharan countries. With this variable we aim to capture any possible external influence of the 'third wave' of democratization on the military regimes in Sub-Saharan Africa. ${ }^{8}$

The appendix reports the summary statistics and definitions (A1), a correlation matrix (A2) and a of list of countries (A3).

\section{Results}

Table 1 shows the coefficients of the spatial estimation of model (2). The availability of the data determines the size of our dataset for the estimations, which includes 40 countries for the 1977-2007 period, that is $40 * 31=1,240$ observations. The per capita GDP has been logged. The models presented in Table 1 differ with respect to the independent variables included in the $X$ vector.

In sum, the results confirm that there is a spatial autocorrelation between military dictatorships. The spatial coefficient $\rho$ is significantly positive at least at the 5\% level across all the five models. The value of the coefficient ranges from 0.17 in model 1 to 0.099 in model 5. These figures confirm the presence of spatial autocorrelation between military dictatorships and allow us to reject the null hypotheses stated in the previous paragraph. The spatial lag coefficient indicates that there is a relevant, robust interdependence in the choice of the government rule.

$O D A_{2005}=\left(O D A_{t}{ }^{*} C P I_{2005}\right) / C P I_{t}$

${ }^{8}$ One could argue that both the third wave of democratization and the soviet influence are dependent on the collapse of the Soviet Union. Our specification controls for this breakthrough event through the time dummies, in particular with the 1987-1992 binary variable. A problem of collinearity between the two variables can be excluded because the fact that a country in our dataset is influenced by the Soviet Union does not affect the share of democracies outside the same dataset. The pair-wise correlation between the two variables is not very high, being about 0.23. 
The coefficients of the control variables exhibit the expected signs. First, GDP per capita is negatively and significantly associated with the dependent variable so indicating that more developed countries have a lower probability of a military regime. If we look at the by-sector share of GDP, the manufacturing share of GDP is negatively and significantly associated with the dependent variable, while the mining share of GDP is significantly positive at the $10 \%$ level.

Openness is negatively but weakly significantly associated with the probability of a military rule. This suggests that whenever a country is integrated within the global economy it is less likely to become a military dictatorship. This is confirmed by the significant and robust coefficient for the dummy landlocked. However, composition of trade is relevant, especially when it involves natural resources subject to expropriation. Oil exporting countries, in fact, are associated with a higher likelihood of a military regime, when the coefficient is significant (models 2, 3, 4). Interesting to note that the lagged ratio $O D A / G D P$, is significantly and negatively associated with the existence of a military regime whereas the count of IMF programs is positively associated with it. The feasible interpretation is that since foreign aid is largely determined by political alliances (as shown in Alesina and Dollar, 2000), military regimes are less likely to be in a friendly relationship with democratic donors. At the same time, the evidence on the IMF loans recalls evidence provided by Barro and Lee (2005).

If we look at the world share of democracies variable, we see that the sign is negative and stable across all the models, confirming the idea of an external influence of the third wave of democratization towards less militarization. The coefficients, however, are never statistically significant. Among the time dummies, only the 1987-1992 one is statistically significant and it is positive: in that period there are more military regimes than after 2002. In fact, if we remove the world share of democracies, the first three time dummies become significantly positive as expected, but all the other coefficients are robust. Therefore, we believe it is because the share of democratic countries increased over time so capturing a trend. Nonetheless, since those variables are not collinear among each other, we prefer to present the most complete specification. 
Table 1 - Concentration of military autocracies

\begin{tabular}{|c|c|c|c|c|c|}
\hline Dep var: military regime dummy & Model 1 & Model 2 & Model 3 & Model 4 & Model 5 \\
\hline Spatial coefficient, $\rho$ & $\begin{array}{c}0.169^{* * *} \\
(0.058)\end{array}$ & $\begin{array}{c}0.141^{* * * *} \\
(0.058)\end{array}$ & $\begin{array}{c}0.134^{* *} \\
(0.059)\end{array}$ & $\begin{array}{c}0.131^{* *} \\
(0.061)\end{array}$ & $\begin{array}{c}0.098^{* *} \\
(0.051)\end{array}$ \\
\hline World Share of democracies & $\begin{array}{l}-1.721 \\
(2.088)\end{array}$ & $\begin{array}{l}-1.849 \\
(2.196)\end{array}$ & $\begin{array}{l}-1.933 \\
(2.122)\end{array}$ & $\begin{array}{l}-2.346 \\
(2.251)\end{array}$ & $\begin{array}{l}-2.489 \\
(2.072)\end{array}$ \\
\hline Ln GDP per capita (t-1) & $\begin{array}{c}-1.157^{* * *} \\
(0.120)\end{array}$ & $\begin{array}{c}-1.009 * * * \\
(0.122)\end{array}$ & $\begin{array}{l}-1.04 * * * \\
(0.114)\end{array}$ & $\begin{array}{c}-1.046^{* * *} \\
(0.124)\end{array}$ & $\begin{array}{c}-0.999 * * * \\
(0.146)\end{array}$ \\
\hline Manufacturing share of GDP (t-1) & $\begin{array}{c}-0.028^{* *} \\
(0.009)\end{array}$ & $\begin{array}{c}-0.038^{* * *} \\
(0.009)\end{array}$ & $\begin{array}{c}-0.038^{* * *} \\
(0.009)\end{array}$ & $\begin{array}{c}-0.038^{* * *} \\
(0.009)\end{array}$ & $\begin{array}{c}-0.056^{* * *} \\
(0.012)\end{array}$ \\
\hline Mining (t-1) & $\begin{array}{c}0.014 * * \\
(0.006)\end{array}$ & $\begin{array}{l}0.009 * * \\
(0.006)\end{array}$ & $\begin{array}{l}0.013^{* *} \\
(0.006)\end{array}$ & $\begin{array}{c}0.011^{* *} \\
(0.005)\end{array}$ & $\begin{array}{c}0.018 * * * \\
(0.007)\end{array}$ \\
\hline Openness (t-1) & $\begin{array}{l}-0.002^{*} \\
(0.002)\end{array}$ & $\begin{array}{l}-0.003^{*} \\
(0.002)\end{array}$ & $\begin{array}{l}-0.004^{* *} \\
(0.003)\end{array}$ & $\begin{array}{c}-0.003^{* *} \\
(0.002)\end{array}$ & $\begin{array}{l}-0.002 \\
(0.002)\end{array}$ \\
\hline OIL exporting country (t-1) & $\begin{array}{c}0.211 \\
(0.185)\end{array}$ & $\begin{array}{c}0.442^{* * *} \\
(0.188)\end{array}$ & $\begin{array}{l}0.321^{* *} \\
(0.194)\end{array}$ & $\begin{array}{l}0.358^{* *} \\
(0.184)\end{array}$ & $\begin{array}{l}-0.059 \\
(0.211)\end{array}$ \\
\hline ODA/GDP (t-1) & $\begin{array}{c}-5.481 * * * \\
(0.932)\end{array}$ & $\begin{array}{c}-4.477^{* * *} \\
(1.026)\end{array}$ & $\begin{array}{c}-4.988^{* * *} \\
(0.996)\end{array}$ & $\begin{array}{c}-4.925^{* * *} \\
(0.971)\end{array}$ & $\begin{array}{c}-3.177^{* * *} \\
(1.14)\end{array}$ \\
\hline IMF programs (t-1) & $\begin{array}{l}0.222^{* *} \\
(0.098)\end{array}$ & $\begin{array}{l}0.217 * * \\
(0.097)\end{array}$ & $\begin{array}{l}0.222^{* *} \\
(0.102)\end{array}$ & $\begin{array}{c}0.235^{* * * *} \\
(0.1)\end{array}$ & $\begin{array}{l}0.191^{* *} \\
(0.104)\end{array}$ \\
\hline Landlocked & & $\begin{array}{c}0.52^{* * *} \\
(0.109)\end{array}$ & $\begin{array}{c}0.404^{* * *} \\
(0.124)\end{array}$ & $\begin{array}{c}0.416^{* * *} \\
(0.117)\end{array}$ & $\begin{array}{c}0.272^{* *} \\
(0.135)\end{array}$ \\
\hline UK & & & $\begin{array}{l}-0.284^{*} \\
(0.115)\end{array}$ & $\begin{array}{c}-0.273^{* * *} \\
(0.104)\end{array}$ & \\
\hline Soviet & & & & $\begin{array}{c}0.019 \\
(0.2)\end{array}$ & $\begin{array}{c}0.889 * * * \\
(0.225)\end{array}$ \\
\hline France & & & & & $\begin{array}{c}-0.106 \\
(0.141)\end{array}$ \\
\hline Spain & & & & & $\begin{array}{c}-1.354^{* * * *} \\
(0.363)\end{array}$ \\
\hline Portugal & & & & & $\begin{array}{c}-1.286^{* * *} \\
(0.258)\end{array}$ \\
\hline Belgium & & & & & $\begin{array}{c}1.718^{* * *} \\
(0.215)\end{array}$ \\
\hline Centre & $\begin{array}{c}0.65^{* * *} \\
(0.28)\end{array}$ & $\begin{array}{c}0.987^{* * * *} \\
(0.311)\end{array}$ & $\begin{array}{c}0.643^{* *} \\
(0.32)\end{array}$ & $\begin{array}{c}0.705^{* *} \\
(0.332)\end{array}$ & $\begin{array}{c}1.335^{* * *} \\
(0.355)\end{array}$ \\
\hline East & $\begin{array}{l}-0.112 \\
(0.287)\end{array}$ & $\begin{array}{c}0.185 \\
(0.327)\end{array}$ & $\begin{array}{l}-0.062 \\
(0.308)\end{array}$ & $\begin{array}{c}0.005 \\
(0.323)\end{array}$ & $\begin{array}{c}-0.002 \\
(0.343)\end{array}$ \\
\hline West & $\begin{array}{c}0.164 \\
(0.264)\end{array}$ & $\begin{array}{c}0.604^{* *} \\
(0.301)\end{array}$ & $\begin{array}{c}0.259 \\
(0.315)\end{array}$ & $\begin{array}{c}0.323 \\
(0.325)\end{array}$ & $\begin{array}{c}0.856^{* * *} \\
(0.349)\end{array}$ \\
\hline Intercept & $\begin{array}{c}8.683^{* * *} \\
(1.414)\end{array}$ & $\begin{array}{c}7.132 * * * \\
(1.476)\end{array}$ & $\begin{array}{c}7.931^{* * *} \\
(1.513)\end{array}$ & $\begin{array}{c}8.114^{* * *} \\
(1.611)\end{array}$ & $\begin{array}{c}7.293^{* * *} \\
(1.604)\end{array}$ \\
\hline 1977-1981 & $\begin{array}{c}0.645 \\
(0.576)\end{array}$ & $\begin{array}{c}0.625 \\
(0.612)\end{array}$ & $\begin{array}{c}0.622 \\
(0.591)\end{array}$ & $\begin{array}{c}0.507 \\
(0.622)\end{array}$ & $\begin{array}{c}0.488 \\
(0.573)\end{array}$ \\
\hline 1982-1986 & $\begin{array}{c}0.636 \\
(0.513)\end{array}$ & $\begin{array}{c}0.631 \\
(0.542)\end{array}$ & $\begin{array}{c}0.625 \\
(0.524)\end{array}$ & $\begin{array}{l}0.524 \\
(0.54)\end{array}$ & $\begin{array}{c}0.569 \\
(0.505)\end{array}$ \\
\hline 1987-1991 & $\begin{array}{c}0.910 * * * \\
(0.376)\end{array}$ & $\begin{array}{l}0.914^{* *} \\
(0.407)\end{array}$ & $\begin{array}{c}0.907^{* *} \\
(0.397)\end{array}$ & $\begin{array}{c}0.827^{* *} \\
(0.406)\end{array}$ & $\begin{array}{c}0.883^{* * * *} \\
(0.373)\end{array}$ \\
\hline 1992-1996 & $\begin{array}{c}0.116 \\
(0.236)\end{array}$ & $\begin{array}{c}0.095 \\
(0.244)\end{array}$ & $\begin{array}{c}0.122 \\
(0.239)\end{array}$ & $\begin{array}{c}0.076 \\
(0.251)\end{array}$ & $\begin{array}{c}0.112 \\
(0.247)\end{array}$ \\
\hline $1997-2001$ & $\begin{array}{l}-0.283^{*} \\
(0.189)\end{array}$ & $\begin{array}{l}-0.247^{*} \\
(0.191)\end{array}$ & $\begin{array}{l}-0.242 \\
(0.198)\end{array}$ & $\begin{array}{l}-0.288^{*} \\
(0.197)\end{array}$ & $\begin{array}{l}-0.246^{*} \\
(0.197)\end{array}$ \\
\hline Observations & 1,240 & 1,240 & 1,240 & 1,240 & 1,240 \\
\hline Log Likelihood & -565.7 & -553.2 & -549.9 & -550.2 & -489.8 \\
\hline $\mathrm{AIC}$ & $1,167.4$ & $1,144.5$ & $1,139.9$ & $1,142.3$ & $1,027.6$ \\
\hline
\end{tabular}


The British colonial origin is also associated with lower likelihood of military dictatorships, which is in line with the results of Acemoglu et al. (2001). In model 5, the dummy SOVIET shows a positive association with the existence of military regimes. In the same Model 5 the Belgian colonization is associated to the largest probability of a military rule than the UK base group, while both the Spanish and the Portuguese colonization is associated to a smaller incidence of military rule.

Since the model exhibits a spatial autoregressive shape, it is necessary to compute both the direct and the indirect effects to evaluate the effective association between the explanatory variables and the existence of a military regime. Following the literature on this topic, we introduce the concept of feedback loops (LeSage and Pace, 2009). In fact, if country $i$ is a neighbor of country $-i$, country $i$ is a second order neighbor to itself, therefore a change in a control variable $x_{-i}$ that affects $y_{-i}$, in turn influences $y_{i}$. Therefore, the direct impacts are interpreted as regression coefficients of a non-spatial linear regression. In fact, they measure the impact of a variation of each control variable in country $i$ on the dependent variable in country $i$, namely the probability of existence of a military dictatorship (Wilhelm and Godinho del Matos, 2013). The indirect effects, on the other hand, represent the impact of a variation of each control variables in country $-i$ on the dependent variable in country $i$. The indirect effects arise from the feedbacks loops that are generated when we consider the neighboring structure impose in the matrix $\boldsymbol{W}$. Put differently, the indirect effect takes shape because of the influence of each variable on the neighbors' probability of a military regime. Then, we compute the total effect as the sum of direct and indirect effect and eventually we measure the feedback which is computed as subtraction between regression coefficients of table 1 and the direct impact (Le Sage and Pace, 2009). Table 2 reports direct, indirect and total effects computed from coefficients of model 5 in table 1.

The coefficients in Table 1 and the relative impacts in Table 2 provide consistent results. That is the coefficient of each covariate has the same sign as each of the impacts (e.g. openness has a negative sign in Table 1, but it is always sign also in Table $2^{9}$ ).

\footnotetext{
9 The only exception id the EAST dummy in model 5: despite the regression coefficient is negative, the indirect impact is positive. Since the coefficient is not statistically significant and the marginal impacts are very close to zero, we can treat this exception as negligible.
} 
Table 2. Feedback, Direct, indirect and total effects of the variables on the probability of a military regime (computed from coefficients of model 5).

\begin{tabular}{|c|c|c|c|c|c|c|c|}
\hline & Direct & Std. error & Indirect & Std. error. & Total & Std. error & Feedback \\
\hline World Share of democracies & -0.542 & 0.450 & -0.061 & 0.066 & -0.603 & 0.503 & -1.948 \\
\hline Ln GDP per capita (t-1) & -0.217 & 0.029 & -0.025 & 0.014 & -0.242 & 0.034 & -0.783 \\
\hline Manufacturing share of GDP (t-1) & -0.012 & 0.002 & -0.001 & 0.001 & -0.014 & 0.003 & -0.044 \\
\hline Mining (t-1) & 0.004 & 0.002 & 0.000 & 0.000 & 0.005 & 0.002 & 0.015 \\
\hline Openness (t-1) & 0.000 & 0.000 & -0.000 & 0.000 & 0.000 & 0.001 & -0.001 \\
\hline OIL exporting country (t-1) & -0.013 & 0.046 & -0.002 & 0.006 & -0.015 & 0.052 & -0.046 \\
\hline Landlocked & 0.059 & 0.029 & 0.007 & 0.005 & 0.066 & 0.032 & 0.213 \\
\hline SOVIET & 0.193 & 0.048 & 0.022 & 0.013 & 0.216 & 0.055 & 0.697 \\
\hline FRANCE & -0.023 & 0.031 & -0.003 & 0.004 & -0.026 & 0.034 & -0.084 \\
\hline SPAIN & -0.294 & 0.078 & -0.034 & 0.019 & -0.328 & 0.086 & -1.061 \\
\hline PORTUGAL & -0.280 & 0.055 & -0.032 & 0.017 & -0.312 & 0.061 & -1.007 \\
\hline BELGIUM & 0.373 & 0.042 & 0.043 & 0.023 & 0.416 & 0.049 & 1.345 \\
\hline ODA/GDP (t-1) & -0.689 & 0.245 & -0.082 & 0.054 & -0.771 & 0.280 & -2.488 \\
\hline IMF programs (t-1) & 0.042 & 0.022 & 0.005 & 0.004 & 0.046 & 0.025 & 0.150 \\
\hline 1977-1981 & 0.106 & 0.124 & 0.013 & 0.018 & 0.119 & 0.140 & 0.383 \\
\hline $1982-1986$ & 0.123 & 0.109 & 0.015 & 0.017 & 0.138 & 0.123 & 0.446 \\
\hline 1987-1991 & 0.192 & 0.080 & 0.023 & 0.016 & 0.214 & 0.091 & 0.692 \\
\hline 1992-1996 & 0.024 & 0.054 & 0.003 & 0.007 & 0.028 & 0.060 & 0.088 \\
\hline $1997-2001$ & -0.054 & 0.043 & -0.006 & 0.007 & -0.060 & 0.048 & -0.193 \\
\hline CENTRE & 0.290 & 0.076 & 0.034 & 0.020 & 0.324 & 0.087 & 1.046 \\
\hline EAST & -0.000 & 0.074 & 0.000 & 0.010 & -0.000 & 0.084 & -0.001 \\
\hline WEST & 0.186 & 0.075 & 0.022 & 0.016 & 0.208 & 0.086 & 0.671 \\
\hline
\end{tabular}

Feedbacks also exhibit the same sign of the coefficients. Looking at the magnitude of the total effects, the negative impact of foreign aid appears to be extremely relevant due, in particular, to the direct effect.

\subsection{Robustness checks}

For sake of robustness we run some robustness checks, which are presented in Table 3 below. In particular the specification is re-estimated separately for the subsamples 1977-1989 and 1990-2007. As noted above, in the aftermath of the Cold War several polities evolved in democracies. Therefore, it is reasonable to assume that relationship between military regimes evolved too. In what follows, the econometric results confirm this idea.

In table 3, we see that while the significant coefficients show the expected signs, the spatial coefficient is positive and significant only after 1989 at the 5\% level. Put briefly, after splitting the time series the spatial autocorrelation is confirmed in the aftermath of Cold War only. That is, the reversal of the Cold War has influenced the spatial diffusion of military regimes. Put differently, once the 
global order of the Cold War vanished, regional factors and linkages became crucial to shape institutional landscape at regional level.

Table 3. Robustness checks

\begin{tabular}{|c|c|c|}
\hline Dep var: military rule dummy & Pre 1989 & Post 198 \\
\hline Spatial coefficient, $\rho$ & $\begin{array}{l}-0.059 \\
(0.077)\end{array}$ & $\begin{array}{c}0.113^{* *} \\
(0.066)\end{array}$ \\
\hline World Share of democracies & -2.563 & -2.212 \\
\hline Ln GDP per capita (t-1) & $\begin{array}{c}(5.136) \\
-1.685^{* * *}\end{array}$ & $\begin{array}{c}(3.274) \\
-0.876^{* * *}\end{array}$ \\
\hline Manufacturing share of GDP (t-1) & $\begin{array}{c}(0.295) \\
-0.053^{* * *} \\
(0.018)\end{array}$ & $\begin{array}{c}(0.167) \\
-0.07 * * * \\
(0.018)\end{array}$ \\
\hline Mining (t-1) & $\begin{array}{c}0.034^{* * *} \\
(0.015)\end{array}$ & $\begin{array}{c}0.017^{* *} \\
(0.009)\end{array}$ \\
\hline Openness (t-1) & $\begin{array}{c}-0.007^{* *} \\
(0.003)\end{array}$ & $\begin{array}{c}0.002 \\
(0.003)\end{array}$ \\
\hline OIL exporting country (t-1) & $\begin{array}{l}0.489^{*} \\
(0.342)\end{array}$ & $\begin{array}{l}-0.464^{*} \\
(0.326)\end{array}$ \\
\hline ODA/GDP (t-1) & $\begin{array}{c}3.993 * * \\
(1.807)\end{array}$ & $\begin{array}{c}-9.925^{* * *} \\
(2.321)\end{array}$ \\
\hline IMF programs (t-1) & $0.278^{* *}$ & 0.126 \\
\hline Landlocked & $\begin{array}{l}(0.152) \\
0.88^{* * *}\end{array}$ & $\begin{array}{c}(0.182) \\
0.051\end{array}$ \\
\hline Soviet & $\begin{array}{c}(0.255) \\
1.771^{* * *} \\
(0.343)\end{array}$ & $\begin{array}{l}(0.191) \\
-0.045 \\
(0.585)\end{array}$ \\
\hline France & $\begin{array}{c}0.081 \\
(0.251)\end{array}$ & $\begin{array}{c}-0.393^{* *} \\
(0.199)\end{array}$ \\
\hline Spain & $\begin{array}{l}-0.285 \\
(0.477)\end{array}$ & $\begin{array}{c}-4.191^{* * *} \\
(1.936)\end{array}$ \\
\hline Portugal & $\begin{array}{c}-2.471^{* * *} \\
(0.421)\end{array}$ & $\begin{array}{r}-1.383^{* * *} \\
(0.422)\end{array}$ \\
\hline Belgium & $\begin{array}{c}1.643^{* * * *} \\
(0.345)\end{array}$ & $\begin{array}{c}1.948^{* * * *} \\
(0.279)\end{array}$ \\
\hline Centre & $\begin{array}{c}1.534^{* * * *} \\
(0.546)\end{array}$ & $\begin{array}{c}1.552^{* * * *} \\
(0.484)\end{array}$ \\
\hline East & $\begin{array}{c}-0.495 \\
(0.517)\end{array}$ & $\begin{array}{c}0.321 \\
(0.468)\end{array}$ \\
\hline West & $\begin{array}{c}1.424^{* * *} \\
(0.531)\end{array}$ & $\begin{array}{l}0.705^{*} \\
(0.469)\end{array}$ \\
\hline $1977-1981$ & $\begin{array}{c}-0.398 \\
(0.424)\end{array}$ & \\
\hline $1982-1986$ & $\begin{array}{l}-0.279 \\
(0.281)\end{array}$ & \\
\hline $1992-1996$ & & $\begin{array}{c}-0.855^{* * *} \\
(0.267)\end{array}$ \\
\hline $1997-2001$ & & $\begin{array}{c}-1.434^{* * *} \\
(0.365)\end{array}$ \\
\hline $2002-2007$ & & $\begin{array}{r}-1.246^{* * *} \\
(0.477)\end{array}$ \\
\hline Intercept & $\begin{array}{c}12.219^{* * * *} \\
(3.151)\end{array}$ & $\begin{array}{c}7.867^{* * * *} \\
(2.031)\end{array}$ \\
\hline Observations & 520 & 720 \\
\hline Log Likelihood & -202.9 & -239.9 \\
\hline $\mathrm{AIC}$ & 447.9 & 523.9 \\
\hline
\end{tabular}


Most covariates confirm the signs of table 1 . The remarkable exception is the sign of the ODA/GDP ratio. In the Cold War period it is positively and significantly associated with the existence of a military regime whereas in the post1989 period it turns to be negatively associated with the dependent variable. This is in line with the idea according to which political linkages and alliances are determinants of foreign aid. That is, in the Cold War period foreign aid was channeled towards allies irrespectively of their internal regime. In the aftermath of the Cold War, once democratization gained momentum, foreign aid turned to be negatively associated with the probability of a military regime. That is, foreign aid did not contribute to militarization of the government but prevented local elites from descending into a military rule. Tables $4 \mathrm{a}$ and $4 \mathrm{~b}$ report the direct and indirect effect of the two robustness checks, for the pre 1989 and post 1989 periods, respectively.

Table 4a. Direct and indirect effects of robustness checks - Pre 1989

\begin{tabular}{lcllllll}
\hline & Direct & Std. error & Indirect & Std. error. & Total & Std. error & Feedback \\
\hline World Share of democracies & -0.536 & 1.080 & 0.021 & 0.098 & -0.516 & 1.039 & -2.027 \\
Ln GDP per capita (t-1) & -0.354 & 0.054 & 0.015 & 0.026 & -0.339 & 0.061 & -1.331 \\
Manufacturing share of GDP (t-1) & -0.011 & 0.004 & 0.001 & 0.001 & -0.011 & 0.004 & -0.042 \\
Mining (t-1) & 0.007 & 0.003 & -0.000 & 0.001 & 0.007 & 0.003 & 0.027 \\
Openness (t-1) & -0.002 & 0.001 & 0.000 & 0.000 & -0.001 & 0.001 & -0.006 \\
OIL exporting country (t-1) & 0.103 & 0.072 & -0.005 & 0.010 & 0.098 & 0.068 & 0.386 \\
Landlocked & 0.185 & 0.053 & -0.009 & 0.014 & 0.177 & 0.050 & 0.695 \\
SOVIET & 0.372 & 0.067 & -0.017 & 0.028 & 0.356 & 0.068 & 1.399 \\
FRANCE & 0.017 & 0.053 & -0.001 & 0.005 & 0.016 & 0.051 & 0.064 \\
SPAIN & -0.060 & 0.101 & 0.003 & 0.009 & -0.057 & 0.096 & -0.225 \\
PORTUGAL & -0.520 & 0.082 & 0.023 & 0.039 & -0.497 & 0.082 & -1.951 \\
BELGIUM & 0.346 & 0.069 & -0.015 & 0.026 & 0.330 & 0.068 & 1.297 \\
ODA/GDP (t-1) & 0.841 & 0.381 & -0.042 & 0.071 & 0.799 & 0.357 & 3.152 \\
IMF programs (t-1) & 0.058 & 0.032 & -0.002 & 0.005 & 0.056 & 0.031 & 0.220 \\
1977-1981 & -0.084 & 0.089 & 0.003 & 0.010 & -0.080 & 0.086 & -0.315 \\
1982-1986 & -0.059 & 0.059 & 0.002 & 0.007 & -0.056 & 0.057 & -0.221 \\
CENTRE & 0.324 & 0.114 & -0.014 & 0.025 & 0.310 & 0.112 & 1.211 \\
EAST & -0.103 & 0.107 & 0.004 & 0.011 & -0.099 & 0.102 & -0.392 \\
WEST & 0.300 & 0.111 & -0.014 & 0.024 & 0.287 & 0.107 & 1.124 \\
\hline & & & & & & & \\
& & & & & & &
\end{tabular}


Table 4b. Direct and indirect effects of robustness checks - Post 1989

\begin{tabular}{lcllllll}
\hline & Direct & Std. error & Indirect & Std. error. & Total & Std. error & Feedback \\
\hline World Share of democracies & -0.392 & 0.582 & -0.051 & 0.097 & -0.443 & 0.663 & -1.820 \\
Ln GDP per capita (t-1) & -0.156 & 0.030 & -0.021 & 0.013 & -0.176 & 0.034 & -0.721 \\
Manufacturing share of GDP (t-1) & -0.012 & 0.003 & -0.002 & 0.001 & -0.014 & 0.004 & -0.058 \\
Mining (t-1) & 0.003 & 0.002 & 0.0004 & 0.000 & 0.004 & 0.002 & 0.014 \\
Openness (t-1) & 0.000 & 0.001 & 0.0001 & 0.000 & 0.000 & 0.001 & 0.002 \\
OIL exporting country (t-1) & -0.082 & 0.058 & -0.011 & 0.012 & -0.093 & 0.066 & -0.382 \\
Landlocked & 0.009 & 0.034 & 0.001 & 0.005 & 0.010 & 0.039 & 0.042 \\
SOVIET & -0.008 & 0.105 & -0.001 & 0.016 & -0.009 & 0.119 & -0.038 \\
FRANCE & -0.070 & 0.036 & -0.009 & 0.008 & -0.079 & 0.040 & -0.324 \\
SPAIN & -0.746 & 0.350 & -0.093 & 0.065 & -0.839 & 0.378 & -3.445 \\
PORTUGAL & -0.246 & 0.077 & -0.034 & 0.025 & -0.280 & 0.092 & -1.138 \\
BELGIUM & 0.345 & 0.048 & 0.046 & 0.026 & 0.391 & 0.050 & 1.603 \\
ODA/GDP (t-1) & -1.760 & 0.410 & -0.237 & 0.146 & -1.997 & 0.464 & -8.165 \\
IMF programs (t-1) & 0.022 & 0.032 & 0.003 & 0.005 & 0.025 & 0.037 & 0.104 \\
1992-1996 & -0.152 & 0.047 & -0.021 & 0.015 & -0.172 & 0.055 & -0.704 \\
1997-2001 & -0.254 & 0.064 & -0.035 & 0.023 & -0.289 & 0.076 & -1.180 \\
2002-2007 & -0.221 & 0.085 & -0.030 & 0.023 & -0.251 & 0.099 & -1.026 \\
CENTRE & 0.276 & 0.087 & 0.038 & 0.027 & 0.314 & 0.102 & 1.277 \\
EAST & 0.057 & 0.083 & 0.009 & 0.015 & 0.066 & 0.096 & 0.264 \\
WEST & 0.125 & 0.084 & 0.018 & 0.018 & 0.143 & 0.097 & 0.580 \\
\hline
\end{tabular}

\section{Concluding remarks}

In this paper we have shown the existence of spatial autocorrelation between military dictatorships in Sub-Saharan Africa from 1977 through 2007. This work exploited a novel definition of military regimes as developed in Hadenius and Teorell (2007). We empirically investigated this issue by applying a Bayesian SAR probit regression, extended to a pooled model. In sum, the main result we would claim for this work is: there is a robust spatial autocorrelation between military governments. In a broader view, these results confirm those emerging from a large literature on the spatial spillover of institutions. This result turns to be even more interesting when considering the enrichment provided by robustness checks. We have re-estimated separately for the sub-periods 1977-1989 and 1990-2007. This was reasonable because in the aftermath of the Cold War several polities evolved in democracies. We found that the spatial coefficient is positive and significant only after 1989. Put briefly, after splitting the time series the spatial autocorrelation is confirmed in the aftermath of Cold War only. That is, the reversal of the Cold War 
has influenced the spatial diffusion of military regimes. Put differently, once the global order of the Cold War vanished, regional factors and linkages became crucial to shape institutional landscape at regional level.

Evidence on covariates also provides interesting insights on the economic correlates of a military rule. In particular there is a negative association between one-year lagged GDP per capita and the existence of a military rule. In particular, in the light of the proper interpretation of GDP per capita as measure of long-run economic growth, we can maintain that poorer countries are more likely to turn into a military rule. The foregoing results are in line with the evidence of larger manufacturing sector associated with a smaller probability of a military rule. Put differently, the expansion of productive sectors decrease the probability of descending into a military rule. This is also confirmed when taking into account the robust negative association between the degree of trade openness and the dependent variable. In this respect, it is reasonable to say that countries which are more integrated in the global economy are also more likely to be affected by the global movement towards democracy rather than a process of spatial concentration of military regimes. Of particular interest is the evidence on the relationship between the foreign aid (computed as the one-year lagged ratio on GDP) and the military government. In the baseline model, foreign aid on GDP is negatively and significantly associated with the current existence of a military government to suggesting that foreign aid may be considered instrumental to prevent the militarization of government. After spitted the time series, we found that the mentioned negative association is confirmed only in the aftermath of the Cold War whereas it was positive before 1989. The reasonable interpretation is that in the Cold War period foreign aid was channeled towards allies irrespectively of their internal regime. Instead, in the aftermath of the Cold War, foreign aid did not contribute to militarization of governments but rather it prevented its emergence. 


\section{References}

Acemoglu D., Johnson, S. and Robinson J.A. (2001). The Colonial Origins of Comparative Development: An Empirical Investigation, American Economic Review 91: 1369-1401.

Acemoglu D., Ticchi D., and Vindigni A. (2010). A Theory of Military Dictatorships, American Economic Journal: Macroeconomics 2: 1-42.

Alesina A., Dollar D., (2000), Who Gives Foreign Aid to Whom and Why? Journal of Economic Growth, 5: 33-63

Barro R.J., Lee J.W., (2005), IMF programs: Who is chosen and what are the effects? Journal of Monetary Economics, 52: 1245-1269

Beck T., Clarke G., Groff A., Keefer P. and Walsh P. (2001). New Tools in Comparative Political Economy: The Database of Political Institutions, World Bank Economic Review 15: 165-176.

Becker S.O., Egger P.H. Seidel T., 2009, Common Political Culture: Evidence on regional corruption contagion, European Journal of Political Economy, vol. 25, n.3, pp. 300-310

Besley, T., \& Persson, T. (2008). Wars and state capacity. Journal of the European Economic Association, 6(2-3), 522-530.

Besley, T., \& Persson, T. (2009). Repression or civil war?. The American Economic Review, 292-297.

Besley T., and Robinson J.A. (2010). Quis Custodiet Ipsos Custodes? Civilian Control over the Military, Journal of the European Economic Association 8: $655-663$.

Boix, C. (2003). Democracy and Redistribution, Cambridge: Cambridge University Press.

Bosker M., Garretsen H., 2008, Economic development and the geography of institutions, Journal of Economic Geography, 9, 295

Brandt, P. T., Freeman, J. R., \& Schrodt, P. A. (2011). Real time, time series forecasting of inter-and intra-state political conflict. Conflict Management and Peace Science, 28(1), 41-64.

Brinks D. and Coppedge M. (2006). Diffusion Is No Illusion. Neighbor Emulation in the Third Wave of Democracy, Comparative Political Studies 39: 463-489. 
Caruso R., Costa J., and Ricciuti R. (2014). The Probability of Military Rule, Africa 1970-2007, in Karl Warneryd (ed.), The Economics of Conflict, MIT Press, Cambridge MA forthcoming.

Caruso R., (2010), Butter, Guns and Ice-Cream, Theory and evidence from SubSaharan Africa. Defence and Peace Economics, 21: 269-283.

Cheibub, J.A., Gandhi, J. and Vreeland, J.R. (2010). Democracy and Dictatorship Revisited, Public Choice, 143: 67-101.

De Groot O.J. (2011). Spillovers of Institutional Change in Africa, Kyklos, 64: 410426.

Di Porto, E. D., \& Revelli, F. (2011). Tax-limited reaction functions, Journal of Applied Econometrics, 28:823-839.

Doorenspleet, R. (2004). The Structural Context of Recent Transitions to Democracy. European Journal of Political Research 43: 309-335.

Dreher, A. (2006). IMF and Economic Growth: The Effects of Programs, Loans, and Compliance with Conditionality. World Development 34: 769-788.

Elkins Z. Simmons B. (2005), On Waves, Clusters, and Diffusion: A Conceptual Framework, Annals of the American Academy of Political and Social Science, 598: $33-51$

Fiva, J. H., \& Rattsø, J. (2007). Local choice of property taxation: Evidence from Norway. Public Choice, 132(3-4), 457-470.

Franzese, R. and Hays, J.C. (2009). The Spatial Probit Model of Interdependent Binary Outcomes: Estimation, Interpretation, and Presentation, paper presented at the 2009 Public Choice Society.

Gandhi, J. (2008). Political Institutions under Dictatorship. New York: Cambridge University Press.

Gassebner M., Lamla M.J., Vreeland J.R., (2013), Extreme Bounds of Democracy, Journal of Conflict Resolution, 57: 171-197.

Geddes, B. (1999). What Do We Know about Democratization after Twenty Years, Annual Review of Political Science 2: 115-144.

Geddes, B. (2003). Paradigms and Sand Castles: Theory Building and Research Design in Comparative Politics, Ann Arbor: The University of Michigan Press.

Geddes, B., Wright, J. and Frantz, E. (2012). Autocratic Regimes Dataset, http://dictators.la.psu.edu 
Goel R., Saunoris J.W., 2014, Global Corruption and the Shadow Economy: spatial aspects, Public Choice, DOI 10.1007/s11127-013-0135-1

Hadenius, A. and Teorell, J. (2007). Pathways from Authoritarianism, Journal of Democracy 18: 143-156.

Heston H., Summers R. and Aten B. (2009). Penn World Table Version 6.3, Center for International Comparisons of Production, Income and Prices at the University of Pennsylvania.

Horny, G., Mendes, R., \& Van den Berg, G. J. (2012). Job Durations With Workerand Firm-Specific Effects: MCMC Estimation With Longitudinal EmployerEmployee Data. Journal of Business \& Economic Statistics, 30(3), 468-480.

Huntington S., (1991), The Third Wave: Democratization in the Late TwentiethCentury. Norman, University of Oklahoma Press

Iqbal, Z., and Starr, H. (2008). Bad Neighbors: Failed States and Their Consequences, Conflict Management and Peace Science, 25: 315-331.

Jacobs, J., Samarina, A., Heijnen, P., \& Elhorst, P. (2013). State transfers at different moments in time: A spatial probit approach (No. 13006-EEF). University of Groningen, Research Institute SOM (Systems, Organisations and Management).

Kakamu, K., and Wago, H. (2005). Bayesian Panel Spatial Probit Model with an Application to Business Cycle in Japan, Proceedings of International Congress on Modeling and Simulations, 856-863.

Kelejian H.H., Murrel Peter, Shepotylo Oleksandr, 2013, Spatial spillovers in the development of institutions, Journal of Development Economics, 101, pp. 297 315.

Leeson P.T., Dean A., (2009), The Democratic Domino Theory: An Empirical Investigation, American Journal of Political Science, 53: 533-551.

LeSage, J. P. (2005). Econometrics toolbox for matlab. Internet site: http://www. spatial-econometrics. com/.(Accessed April 28, 2005).

LeSage, J. and Pace R. K., (2009). Introduction to Spatial Econometrics, CRC Press/Taylor \& Francis Group.

Li, R.P.Y., and Thompson, W.R. (1975). The 'Coup Contagion' Hypothesis. Journal of Conflict Resolution, 19: 63-88.

McGuire, M. C., and M. Olson. 1996. The economics of autocracy and majority rule. Journal of Economic Literature 34:72-96 
McMillen, D. P. (1992). Probit with spatial autocorrelation. Journal of Regional Science, 32(3), 335-348.

Montalvo J.G., Reynal-Querol M. (2005). Ethnic diversity and economic development. Journal of Development Economics, 76: 293- 323.

Neumayer, E., and Plümper, T. (2010). Galton's Problem and Contagion in International Terrorism along Civilizational Lines. Conflict Management and Peace Science, 27: 308-325.

O'Loughlin J., Anselin L., (1991), Bringing Geography back to the Study of International Relations: Spatial Dependence and Regional Context in Africa, 1966-1978, International Interactions, 17:29-61

O'Loughlin J., Ward M.D., Lofdahl C.L., Cohen J.S., Brown D.S., Reilly D., Gleditsch K.S., Shin M., (1998), The Diffusion of Democracy, 1946-1994, Annals of American Geographers, 88: 545-574

Pinkse, J., \& Slade, M. E. (1998). Contracting in space: An application of spatial statistics to discrete-choice models. Journal of Econometrics, 85(1), 125-154.

Posner, D.N., and Young, D.J. (2007). The Institutionalization of Political power in Africa, Journal of Democracy, 18: 126-140.

Przeworski, A., and Limongi, F. (1997). Modernization: Theories and Facts. World Politics, 49: 155-183.

Regan, P.M., Frank, R.W., and Clark, D.H. (2009). New Dataset on Political Institutions and Elections, 1972-2005, Conflict Management and Peace Science, 26: 286-304.

Rowley C.K., (2000), Political culture and economic performance in Sub-Saharan Africa, European Journal of Political Economy, 16(1), pp. 133-158

Schone, K., Koch, W., \& Baumont, C. (2013). Modeling local growth control decisions in a multi-city case: Do spatial interactions and lobbying efforts matter?Public Choice, 154(1-2), 95-117.

Starr, H. (1991). Democratic Dominoes. Diffusion Approaches to the Spread of Democracy in the International System, Journal of Conflict Resolution, 35: 356-381.

Seya, H., Tsutsumi, M., \& Yamagata, Y. (2012). Income convergence in Japan: A Bayesian spatial Durbin model approach. Economic Modelling, 29(1), 60-71. 
Starr, H., Lindborg C., (2003), Democratic Dominoes Revisited: the Hazards of Governmental Transitions, 1974-1996, Journal of Conflict Resolution, 47: 490-519

Strang D., (1991), Adding Social Structure to Diffusion Models, An Event History Framework, Sociological Methods and Research, 19: 324-353

Tullock G., (1987), Autocracy, Kluwer, Dordrecht.

Tullock G., (2002), Undemocratic Governments, Kyklos, vol. 55, n.2, pp. 247-264

Wahman, M., Teorell, T. and Hadenius, A. (2013). Authoritarian Regime Types Revisited: Updated Data in Comparative Perspective, Contemporary Politics, 19: $19-34$.

Wilhelm, Stefan and Miguel Godinho de Matos. 2013. Estimating Spatial Probit Models in R. The R Journal, 5:130-143.

Wintrobe, R. 1990. The Tin Pot and the Totalitarian: An Economic Theory of Dictatorship. American Political Science Review 84: 849-72

Wintrobe, R. 1998. The Political Economy of Dictatorship. Cambridge: Cambridge University Press 
APPENDIX - A1 - Variables, descriptive statistics and sources (Observations=1240)

\begin{tabular}{|c|c|c|c|c|c|c|}
\hline Variable & Description & Source & Mean & Std. Dev. & Min & Max \\
\hline Military & Dummy $=1$ if the government is military & $\begin{array}{l}\text { The Authoritarian Regime Dataset } \\
\text { http://www.svet.lu.se/ARD/ }\end{array}$ & 0.304 & 0.46 & 0 & 1 \\
\hline GDP per capita & GDP/population & $\begin{array}{l}\text { Penn World Tables } \\
\text { http://www.rug.nl/research/ggdc/data/penn-world-table }\end{array}$ & 2317.8 & 2389.3 & 153.2 & 23444.7 \\
\hline Manuf & value added of the agricultural sector & $\begin{array}{l}\text { UNCTAD-STAT } \\
\text { http://unctadstat.unctad.org }\end{array}$ & 10.442 & 6.787 & 0.03 & 40.2 \\
\hline Mining & value added of the mining sector & $\begin{array}{l}\text { UNCTAD-STAT } \\
\text { http://unctadstat.unctad.org }\end{array}$ & 10.2 & 14.6 & 0.02 & 92.4 \\
\hline Openness & trade openness/GDP & $\begin{array}{l}\text { Penn World Tables } \\
\text { http://www.rug.nl/research/ggdc/data/penn-world-table }\end{array}$ & 65.2 & 38.5 & 1.9 & 263.9 \\
\hline Oilprod & $\begin{array}{l}\text { Dummy }=1 \text { if the share of oil } \\
\text { export exceeds } 10 \%\end{array}$ & $\begin{array}{l}\text { CIA World Factbook } \\
\text { https://www.cia.gov/library/publications/the-world-factbook/ }\end{array}$ & 0.17 & 0.376 & 0 & 1 \\
\hline $\begin{array}{l}\text { ODA/GDP } \\
\text { IMF programs }\end{array}$ & $\begin{array}{l}\text { Official Development Assistance flow/GDP } \\
\text { Number of IMF arrangements agreed } \\
\text { (types: Standby, Extended Fund Facility, } \\
\text { Structural Adjustment Facility, Poverty } \\
\text { Reduction and Growth Facility) }\end{array}$ & $\begin{array}{l}\text { World Bank and Penn World Tables } \\
\text { Dreher (2006) }\end{array}$ & $\begin{array}{l}0.051 \\
0.217\end{array}$ & $\begin{array}{l}0.058 \\
0.447\end{array}$ & $\begin{array}{c}-0.001 \\
0\end{array}$ & $\begin{array}{c}0.7 \\
2\end{array}$ \\
\hline Landlocked & Dummy $=1$ if the country is landlocked & own calculations & 0.375 & 0.484 & 0 & 1 \\
\hline Central & $\begin{array}{l}\text { Dummy }=1 \text { if the country is } \\
\text { geographically located in the centre }\end{array}$ & own calculations & 0.225 & 0.418 & 0 & 1 \\
\hline East & $\begin{array}{l}\text { Dummy }=1 \text { if the country is } \\
\text { geographically located in the east }\end{array}$ & own calculations & 0.3 & 0.458 & 0 & 1 \\
\hline West & $\begin{array}{l}\text { Dummy=1 if the country is } \\
\text { geographically located in the west }\end{array}$ & own calculations & 0.375 & 0.484 & 0 & 1 \\
\hline
\end{tabular}


in the sphere of influence of the Soviet Union

France

Dummy $=1$ if the country was a former French colony

Spain Dummy=1 if the country was a former Spanish colony

Portugal Dummy=1 if the country was a former Portuguese colony

Belgium Dummy=1 if the country was a former Belgian colony 
A2 - Correlation matrix $\left({ }^{*}=\right.$ significance level at least $\left.95 \%\right)$

\begin{tabular}{|c|c|c|c|c|c|c|c|c|c|c|c|c|c|c|c|c|c|c|}
\hline & Military & DEM & GDP pc & MANUF & MIN & OPEN & OIL & LANDL & UK & SOVIET & FRA & SPAIN & POR & BEL & $\begin{array}{l}\text { ODA } \\
/ \text { GDP } \\
\end{array}$ & $\begin{array}{l}\text { IMF } \\
\text { prog. }\end{array}$ & CEN & EAST \\
\hline DEM & $-0.24^{*}$ & 1 & & & & & & & & & & & & & & & & \\
\hline GDP pc & $-0.29^{*}$ & -0.01 & 1 & & & & & & & & & & & & & & & \\
\hline MANUF & $-0.15^{*}$ & $-0.07^{*}$ & $0.23^{*}$ & 1 & & & & & & & & & & & & & & \\
\hline MIN & $-0.09^{*}$ & $0.12^{*}$ & $0.56^{*}$ & $-0.23^{*}$ & 1 & & & & & & & & & & & & & \\
\hline OPEN & $-0.23^{*}$ & $0.09^{*}$ & $0.49^{*}$ & $0.06^{*}$ & $0.45^{*}$ & 1 & & & & & & & & & & & & \\
\hline OIL & $0.07^{*}$ & 0.03 & $0.3^{*}$ & $-0.21^{*}$ & $0.67^{*}$ & $0.19^{*}$ & 1 & & & & & & & & & & & \\
\hline LANDL & $0.10^{*}$ & 0 & $-0.14^{*}$ & $0.23^{*}$ & $-0.18^{*}$ & -0.02 & $-0.33^{*}$ & 1 & & & & & & & & & & \\
\hline UK & $-0.20^{*}$ & 0 & $0.16^{*}$ & $0.21^{*}$ & $-0.09^{*}$ & 0.04 & $-0.25^{*}$ & 0.02 & 1 & & & & & & & & & \\
\hline SOVIET & $0.12^{*}$ & $-0.23^{*}$ & 0.01 & 0.02 & $0.06^{*}$ & $-0.06^{*}$ & $0.20^{*}$ & $-0.07^{*}$ & $-0.21^{*}$ & 1 & & & & & & & & \\
\hline FRA & 0.05 & 0 & $0.09^{*}$ & -0.04 & $0.06^{*}$ & -0.001 & $0.13^{*}$ & -0.02 & $-0.55^{*}$ & -0.02 & 1 & & & & & & & \\
\hline SPAIN & $-0.06^{*}$ & 0 & $0.14^{*}$ & $-0.22^{*}$ & $0.24^{*}$ & $0.21^{*}$ & $0.13^{*}$ & $-0.12^{*}$ & $-0.14^{*}$ & -0.03 & $-0.11^{*}$ & 1 & & & & & & \\
\hline POR & $-0.12^{*}$ & 0 & $-0.08^{*}$ & -0.01 & $0.08^{*}$ & 0.01 & $0.12^{*}$ & $-0.22^{*}$ & $-0.25^{*}$ & $0.33^{*}$ & $-0.21^{*}$ & -0.04 & 1 & & & & & \\
\hline BEL & $0.33^{*}$ & 0 & $-0.24^{*}$ & 0.03 & $-0.11^{*}$ & $-0.22^{*}$ & $0.12^{*}$ & $0.17^{*}$ & $-0.25^{*}$ & $-0.06^{*}$ & $-0.21^{*}$ & -0.04 & $-0.08^{*}$ & 1 & & & & \\
\hline ODA/GDP & 0.05 & $-0.12^{*}$ & $-0.48^{*}$ & $-0.19 *$ & $-0.26^{*}$ & -0.05 & $-0.25^{*}$ & -0.04 & $-0.12^{*}$ & $-0.09^{*}$ & $-0.09^{*}$ & 0.01 & $0.21^{*}$ & 0.003 & 1 & & & \\
\hline IMF prog. & $0.08^{*}$ & $-0.09^{*}$ & -0.04 & -0.01 & $-0.06^{*}$ & -0.05 & -0.02 & -0.02 & -0.02 & $-0.06^{*}$ & $0.10^{*}$ & -0.03 & $-0.08^{*}$ & -0.0002 & 0.05 & 1 & & \\
\hline CEN & $0.13^{*}$ & 0 & $0.2^{*}$ & $-0.16^{*}$ & $0.39^{*}$ & $0.082^{*}$ & $0.52^{*}$ & $-0.17^{*}$ & $-0.24^{*}$ & $0.13^{*}$ & $0.23^{*}$ & $0.29^{*}$ & $0.07^{*}$ & $0.07^{*}$ & $-0.17^{*}$ & -0.02 & 1 & \\
\hline EAST & -0.03 & 0 & $-0.22^{*}$ & $0.08^{*}$ & $-0.29^{*}$ & $-0.31^{*}$ & $-0.29^{*}$ & $0.28^{*}$ & $0.28^{*}$ & $0.08^{*}$ & $-0.48^{*}$ & $-0.10^{*}$ & 0.02 & $0.22^{*}$ & 0.04 & 0.004 & $-0.35^{*}$ & 1 \\
\hline WEST & 0.02 & 0 & $-0.21^{*}$ & $-0.13^{*}$ & $-0.12^{*}$ & -0.04 & $-0.07^{*}$ & $-0.28^{*}$ & $-0.28^{*}$ & $-0.14^{*}$ & $0.40^{*}$ & $-0.12^{*}$ & -0.02 & $-0.22^{*}$ & $0.18^{*}$ & $0.08^{*}$ & $-0.41^{*}$ & $-0.51^{*}$ \\
\hline
\end{tabular}




\section{A3 - List of countries in the dataset}

Angola, Benin, Botswana, Burkina Faso, Burundi, Cameroon, Central African Republic, Chad, Congo Dem. Rep., Congo Republic, Cote d'Ivoire, Djibouti, Equatorial Guinea, Eritrea, Ethiopia, Gabon, Gambia, Ghana, Guinea, Guinea-Bissau, Kenya, Lesotho, Liberia, Malawi, Mali, Mauritania, Mozambique, Namibia, Niger, Nigeria, Rwanda, Senegal, Sierra Leone, Somalia, South Africa, Sudan, Swaziland, Tanzania, Togo, Uganda, Zambia, Zimbabwe. 